eu chamaria de transferência e mesmo de 'um efeito de verdade'. 10 x Freud vem participar dessa transferência e desse efeito de verdade.

Recebido em 29/9/2005.

Aprovado em 17/ 10/ 2005.

Angélica Bastos

abastosg@terra.com.br

\section{À PROCURA DO ESTABELECIMENTO DE TRÂNSITO E MOBILIDADE}

Limites. Marta Rezende Cardoso (org.)

São Paulo: Escuta, 2004, 220 p.

\section{Pedro Luiz Ribeiro de Santi \\ Psicanalista; professor de psicologia clínica: teoria psicanalítica, na Cogeae/ PUC-SP e na Faculdade de Comunicação Social da ESPM . É autor de A crítica ao eu na M odernidade. Em M ontaignee Freud (Casa do Psicólogo, 2003), entre outros estudos sobre psicanálise e subjetividade.}

Já faz algum tempo que a clínica e a produção teórica psicanalítica têm sido dominadas pela reflexão sobre os casos-limite. Sua discussão vem de longa data desde os casos difíceis tratados por Ferenczi. Hoje, porém, ela invadiu definitivamente a cena psicanalítica.

Para além de um quadro a mais a ser estudado dentro da psicopatologia psicanalítica, os casos-limite trouxeram uma crise a todo o campo. Da formulação inicial, segundo a qual aqueles pacientes não poderiam ser atendidos de modo adequado no enquadre freudiano, constituiu-se uma nova clínica, com base na escola das relações de objeto.
Contudo, não se trata apenas da descoberta de outras estruturas psicopatológicas a serem incorporadas ao quadro anterior. Todo ele se altera, visivelmente. É muito comum, por exemplo, que pacientes identificados como histéricos na clínica freudiana sejam considerados casos-limite nesta nova clínica.

Com a discussão se estendendo a outras formas de sofrimento mental que chegam cada vez mais aos contextos clínicos (somatizações, adições, distúrbios da ansiedade ou da representação corporal, etc.), o novo paradigma clínico vem se consolidando como aquele capaz de dar conta das novas patologias.

Nada de estranho em se pensar em formas de sofrimento precipitadas por condições contemporâneas de vida. E nada de estranho em se pensar na criação de enquadres de sessão mais adequados, dentro da perspectiva ética e teórica da psicanálise. Estranho é o alarde e a pressa com que se decreta a morte e desinteresse de toda uma tradição psicanalítica: do próprio Freud, passando por autores como Lacan ou Laplanche. Eles não teriam mais nada a nos dizer sobre a clínica contemporânea. Estabelece-se, assim, um limite: fim de um modelo, início de outro radicalmente outro.

Treinada para perceber lapsos, repetições ou omissões, nossa escuta é chamada ante o decreto da morte da clínica freudiana, com seu todo corpo conceitual: sexualidade, recalque, fantasia, inconsciente, realidade psíquica.

Se é mais do que claro que o modelo freudiano não pode dar conta de determinadas formas de sofrimento, é também claro que tal virada de página na história psicanalítica soa sintomática.

A coletânea Limites, de Marta Rezende Cardoso, vem colocar em discussão, de forma original, esta problemática. Se os 
casos-limite sofrem da injunção de dois limites (interno-externo e o constituído pelo recalque), a autora expande a discussão para os limites da própria psicanálise. N ote-se que o título se refere ao estatuto dos limites em geral, não os dos casos-limite, especificamente.

A opção da autora (em sua apresentação e no artigo na qual é co-autora), e de muitos dos autores da coletânea, é procurar colocar-se numa posição de trânsito possível entre os limites das tendências da psicanálise, mais do que optar por algum dos lados. Não se trata, aqui, portanto, de um panfleto no qual se reclama a legitimidade do próprio corpo teórico em desqualificação das posições distintas. Todos sabemos o quão facilmente os psicanalistas evocam a "acusação" de resistência a todos aqueles que com eles não concordem...

Há, assim, uma relação curiosa entrea própria metapsicologia dos casos-limite (oscilação entre o totalmente fechado e o totalmente aberto) e o trabal ho requerido para sustentar a posição de trânsito, comunicação e flexibilidade. Marta Cardoso já havia procurado mover-se neste terreno instável em obra anterior, também organizada por ela: Adolescência: reflexões psicanalíticas (Rio de Janeiro: Nau, 2001).

0 primeiro artigo de limite chama-se "Lendo André Green: o trabalho do negativo e paciente limite", de Luís Claudio Figueiredo e Elisa Cintra. Toda a questão da possibilidade de se habitar entre e através de limites já está colocada aí. Green é, hoje, com certeza, o autor mais importante a estudar o tema. E ele reúne a tradição norte-americana de se tratar os casos-limite como uma estrutura psíquica específica e não como um estado passageiro; uma sólida formação francesa; e o reconhecimento de que foi a escola inglesa da psicanálise a que mais contribuiu para a clínica contemporânea. Além disso, ele se coloca numa posição de franco confronto com Jean Laplanche, psicanalista de referência para os demais autores da coletânea. Que dois psicanalistas brasileiros - um, trazendo forte formação filosófica e histórica e autor de uma extensa obra sobre subjetividade, e outra, grande conhecedora de Melanie Klein assinem o artigo só reforçam esta idéia.

Predominam nos outros artigos os autores de uma tradição mais próxima a Freud e Laplanche. Aqui, também de maneira sintomática, as expressões 'nova clínica' ou 'novas doenças da alma' vêm sempre entre aspas, revelando desconforto e certa suspeita com relação a tais expressões. De um lado, limites identitários estão sendo repuxados e nenhum ego é livre da resistência narcísica a isto. De outro, estes autores vêm lembrar daquilo que parece ser o fundamento mesmo da psicanálise e que parece... recalcado no discurso da nova clínica: o recalque à sexualidade.

Destaco, neste sentido, o artigo de Maria Teresa Melo de Carvalho: 'Sobre o alcance e os limites do recalcamento nas chamadas 'psicopatologias da contemporaneidade'". De forma extremamente concisa e profunda, a autora consegue apresentar todo o campo da discussão desde a colocação em questão do próprio estatuto das novas patologias até o resgate da questão do sexual e do recalque.

No debate entre estas tradições da psicanálise, há algumas confusões de linguagens a serem resolvidas. Quando se diz - tendo como referência Winnicott, por exemplo - que a questão nos casos limites é pré-sexual, na medida que estaríamos operando num registro de necessidades em tono dos cuidados maternos, traumatismos e no qual a relação eu/ objeto ainda não foi devidamente 
constituída, percebe-se que o sexual é entendido como aquilo que Freud chama de 'genital'. Para al guém que conheça minimamente Freud, o que pode ser mais sexual do que o traumático e os cuidados maternais?

Enquanto alguns dos artigos constroem 0 debate teórico nestes termos, outros se dirigem de modo específico à clínica: transferência, técnica, anorexia, a criação artística, etc.

Em conclusão, Marta Cardoso, e todos os autores desta coletânea, realizam um trabal ho corajoso: aventurar-se no campo dos limites munidos da referência freudiana, para estabelecer um trânsito entre diferentes enfoques psicanalíticos. De um lado, reconhecendo os ganhos fundamentais trazidos à clínica psicanalítica pela dimensão das relações de objeto e, de outro, reintroduzindo na psicanálise contemporânea algo que grita pela ausência. Isso que é, afinal, mais do que o próprio inconsciente, a verdadeira praga postulada por Freud e que, por isso, sempre se tenta velar: 0 sexual.

Recebido em 6/9/2005.

Aprovado em 26/ 9/2005.

Pedro Luiz Ribeiro de Santi plrsanti@uol.com.br 